\title{
Effect of Sex of Desert and Taggar Kids on Growth Performance under Extensive System in South Kordofan State
}

\author{
I. Bushara ${ }^{1}$, Mohamed, O. Mudalal ${ }^{1}$, Hind, A. Salih ${ }^{1}$, A.O. Idris ${ }^{2}$, O.M.A. Abdelhadi ${ }^{1}$, \\ M.B. Elemam ${ }^{3}$, Dafalla M.Mekki ${ }^{1}$ \\ ${ }^{1}$ Department of Animal Production. Faculty of Natural Resources and Environmental Studies, \\ University of Kordofan El-Obied, Sudan. \\ ${ }^{2}$ Department of Animal Production, Faculty of Natural Resources and Environmental Studies, 4 Peace \\ University, El Fulla, Sudan \\ ${ }^{3}$ Department of Animal Production, Faculty of Agriculture and Natural Resources, University of \\ Kassala, New-Halfa, Sudan
}

\begin{abstract}
Thirty five male and female Sudan Desert and Taggar goat kids has been investigated to study the effect of sex of kids on birth weight, growth rate and weaning weight of Desert and Taggar goats under traditional management system depended on natural grazing in South Kordofan state at Al Debabat locality. The result revealed that Desert male kids had significantly $(p<0.0 \mathrm{l})$ higher birth weight $(2.25 \pm 0.08 \mathrm{~kg})$ than Taggar male kids $(2.00 \pm 0.06 \mathrm{~kg})$ and Taggar female kids had a significantly $(p<0.0 \mathrm{l})$ lower birth weight $(1.91 \pm 0.04)$ than Desert female kids $(2.08 \pm 0.10 \mathrm{~kg})$. The growth rate for three month of age was significantly $(p<0.0 l)$ higher for desert male and female kids compared with male and female of Taggar kids. Large body weight gain per day $(p<0.0 l)$ scored by Desert kid. Sex of kids had higher significantly $(p<0.0 l)$ effect on body weight at weaning, where Desert male kids had significantly $(p<0.0 \mathrm{l})$ higher weaning weight $(11.88 \pm 0.45 \mathrm{~kg})$ than Taggar male kids $(8.70 \pm 0.20 \mathrm{~kg})$ and Desert female kids had a significantly $(p<0.0 \mathrm{l})$ higher weaning weight $(10.07 \pm 0.20)$ than Taggar female kids $(8.12 \pm 0.28 \mathrm{~kg})$. Also there was significantly $(p<0.0 \mathrm{l})$ higher between male and female of Desert kids.
\end{abstract}

Keywords: Taggar, Desert, goat, growth performance, traditional, Sudan.

\section{INTRODUCTION}

Goat contributes largely to the livelihoods of the livestock keeping households of low-and mediuminput farmers, many of whom have few resources beyond their smallholdings and livestock. In addition, goats are known to be potential genetic resources for meat, milk, skin and fiber. They also play an important role in the socio-economic life of the people as they feature prominently in sociocultural functions like ceremonies and religious festivities. Over the last $20 \mathrm{yr}$, goats have shown the largest increase in numbers among all domestic animals used as livestock (Dubeuf and Boyazoglu, 2009). The population of goat in the world was approximately 807 millions of which Indian houses of about $25 \%$ of the total population by 195 millions (FAOSTAT, 2007). Goats are widely distributed in the tropics and subtropics as a result of the ability to adapt to a variety of environments. The goats are widely spread in all Sudan states and play a substantial economic role in the live hood of many families in urban and rural areas, goats are important to the subsistence needs as they can provide abundant regular supply of meat, milk, fiber and skin. (Elsharif, 2003). Goats are bred for meat and milk production (Dossa et al., 2007 and Jimmy et al., 2010). Desert and Taggar goats were found in Western Sudan particularly in Kordofan states, they are meat types. Generally goats in Sudan are raised traditionally depend on range land. Productivity from goats in the extensive system is said to be poor with a low weaning rate, a high mortality rate and low turnover (Bembridge and Tapson, 1993). Thus, traits affecting economic viability include those associated with growth. Growth is the most important trait in small ruminant production affecting the contribution of the sector to the farm household thru live animal sale and meat production. (Belay and Mengistie, 2013). Body weight and growth rate at different ages are of highly economic importance which vary among goat breeds (Tabbaa et al., 2005). Body weight and rate of gain are among the most economically important and easily measured traits of meat animals. Although weight is an important objective in selection, 
knowledge of the phenotypic and genetic parameters of the growth trait upon which to base selection is of utmost importance. For that reasons the aim of this study is to evaluation the effect of sex on growth rate from birth to weaning time of Desert and Taggar kids managed during rainy season in South Kordofan state, Sudan.

\section{MATERIALS AND MeTHODS}

The present study was conducted in South Kordofan state at Al Debabat locality (100 km south of ELObeid) which lies within the medium rain $(500 \mathrm{~mm})$ woodland savannah (longitudes $12.39^{\circ} \mathrm{N}$, Latitudes $29.48^{\circ} \mathrm{E}$ ). The soil types varied from sandy (goz) in north to heavy clays (vertisoil) in the south. The mean monthly temperature ranged from $31.3 \mathrm{C}^{\circ}$ in April to $25.8 \mathrm{C}^{\circ}$ in July, annual rainfall ranging between 500-800 mm, with peak rain in August (S.K.D.P, 2000)

\subsection{Experimental Animal's Management and Diets}

Thirty five male and female Sudanese goat kids (18 Sudanese Desert kids and 17 Taggari kids) were used in this experiment. The kids were born during the period rainy season of year 2012, to parent stock were advanced pregnant does (12 Desert goats and 12 Taggar goats) raised on traditional management. All animals were treated with the necessary medication against endo-and ecto-parasites and vaccinated against Anthrax and Hemorrhagic Septicemia. The animals were ear tagged, weighted and divided into two groups as group A is Taggar goats (does and kids) group B is Desert goats (Does and kids). The grazing zone of these animals was in the around the study area, the parent stock was prepared to be kidding during the beginning of the rainy season. The two breed were divided into two groups. All goats and their kids were allowed day grazing from $8.00 \mathrm{am}$ to $6.00 \mathrm{pm}$ and in the evening they were kept indoors in enclosures. Watering was once a day from running surface water (Khors) during the early wet season and from excavated ponds at the end of the season. Kids born to these goats were allowed to freely suckle colostrum for the first three days after parturition, thereafter they were separated from their dams during the day. In the evening half of their dam milk was milked before kids were released to spend the night with their dams. Kids were weaned at three month of age. The birth weight was taken immediately after birth and when kids were dry. All kids were then weighed at weekly intervals up to age at first kidding; the animals were weighed in the morning.

\subsection{Statistical Analysis}

All the data obtained from the experiment were analyzed with, means and standard errors of the different traits were computed. Analysis of variance was performed in accordance to general linear method. Duncan`s multiple range test was used with factors that had significant effect on the traits studied. All techniques of the statistical analysis were conducted using Statistical Package for the Social Sciences, software package (SPSS, 1999).

\section{RESULTS}

\subsection{Effect of Sex on Birth Weight}

Sex of kids had highly significant $(\mathrm{p} \leq 0.01)$ effect on birth weight. Male kids were heavier than female kids. The birth weight of Desert and Taggar goat's kids is shown in (Table 1). Type of breed exerted a significant $(p \leq 0.001)$ effect on kids' birth weight, also the effect of sex within same breed was significant ( $\leq \leq 0.05)$. Average birth weight of male and female Desert goats kids were $2.25 \pm 0.08$, $2.08 \pm 0.10 \mathrm{~kg}$ respectively, and average birth weight of male and female Taggar goats kids were $2.00 \pm 0.06$ and $1.91 \pm 0.04 \mathrm{~kg}$ respectively. The weight difference between Desert and Taggar males was about $250 \mathrm{~g}$, and between Desert and Taggar female about $180 \mathrm{~g}$

Table1. Effect of sex on birth weight of Sudanese goats (means \pm SE)

\begin{tabular}{|l|c|c|l|l|}
\hline Variable & No & Male & No & Female \\
\hline Taggar goats & 8 & $2.00 \pm 0.06^{\mathrm{b}}$ & 9 & $1.91 \pm 0.04^{\mathrm{b}}$ \\
\hline Desert goats & 8 & $2.25 \pm 0.08^{\mathrm{a}}$ & 10 & $2.08 \pm 0.10^{\mathrm{a}}$ \\
\hline
\end{tabular}

${ }^{a b}$ Values in the same columns followed with different letters are significant at $P<0.05$

From Table 1, it can be seen that the birth weight of male and female were varied in two breeds. The average birth weight of Desert male kids were higher $(p \leq 0.05)$ than the female kids. The mean birth weight of Taggar male kids were higher $(p \leq 0.05)$ than female kids. The mean birth weights of both sexes of Desert were higher than Taggar. The birth weight depends on breed, feeding, location, care and management e.g., overall health hygiene of pregnant does. The weight difference between males and female in each breed was about $90 \mathrm{~g}$ and $170 \mathrm{~g}$ for Taggar and Desert respectively 


\subsection{Effect of Sex on Growth Rate}

Type of sex exerted a significant $(\mathrm{p} \leq 0$. 001) effect on kids' growth rate at different ages, also the effect of sex within same breed was significant $(\mathrm{p} \leq 0$. 05) on growth rate at different ages (Table 2). However Desert male kids were scored heavier weights as $4.34 \pm 0.12,7.36 \pm 0.37$ and $11.88 \pm 0.45 \mathrm{~kg}$ at 30,60 and 90 days respectively, than Taggar male kids which recorded lighter weights as $3.40 \pm 0.15,3.40 \pm 0.15$ and $8.70 \pm 0.20$ at 30,60 and 90 days respectively.

Table2. Effect of sex on growth rate of Sudanese goat $s$ (means \pm SE)

\begin{tabular}{|c|c|c|c|c|c|}
\hline Breed type & N & 30 days & 60 days & 90 days & Gain /day/ g \\
\hline \multicolumn{7}{|c|}{ Male kids } \\
\hline Taggar & 8 & $3.40 \pm 0.15^{\mathrm{b}}$ & $5.42 \pm 0.15^{\mathrm{b}}$ & $8.70 \pm 0.20^{\mathrm{b}}$ & $74.52 \pm 2.06^{\mathrm{b}}$ \\
\hline Desert & 7 & $4.34 \pm 0.12^{\mathrm{a}}$ & $7.36 \pm 0.37^{\mathrm{a}}$ & $11.88 \pm 0.45^{\mathrm{a}}$ & $1.07 \pm 5.42^{\mathrm{a}}$ \\
\hline \multicolumn{7}{|c|}{ Female kids } \\
\hline Taggar & 8 & $3.25 \pm 0.38^{\mathrm{b}}$ & $5.26 \pm 0.37^{\mathrm{b}}$ & $8.13 \pm 0.28^{\mathrm{b}}$ & $69.76 \pm 2.35^{\mathrm{b}}$ \\
\hline Desert & 8 & $4.31 \pm 0.23^{\mathrm{a}}$ & $6.68 \pm 0.22^{\mathrm{a}}$ & $10.07 \pm 0.20^{\mathrm{a}}$ & $87.98 \pm 1.56^{\mathrm{a}}$
\end{tabular}

${ }^{a b}$ Values in the same columns followed with different letters are significant at $P<0.001$

Female of Desert kids also scored higher significantly $(\mathrm{p} \leq 0$. 001) growth rate at different ages, as $4.31 \pm 0.23,6.68 \pm 0.22$ and $10.07 \pm 0.20 \mathrm{~kg}$ compared with Taggar female kids which recorded $3.25 \pm 0.38$, $5.26 \pm 0.37$ and $8.13 \pm 0.28 \mathrm{~kg}$ at 30,60 and 90 days respectively. From (Table 2) the male kids scored higher $(\mathrm{p} \leq 0.05)$ weight than female in same breed in different time of ages. Also sex significantly $(\mathrm{p} \leq 0.001)$ affect daily body weight gain from birth to weaning period in three months, where Desert male and female scored higher gain (1.07 \pm 5.42 and87.98 $\pm 1.56 \mathrm{~g}$ respectively) than Taggar male and female kids (74.52 \pm 2.06 and69.76 \pm 2.35 g respectively). Male kids in each breed had higher $(p \leq 0.05)$ gain than female part.

\subsection{Effect of Sex on Weaning Weight}

Type of sex exerted a significant $(\mathrm{p} \leq 0$. 001) effect on kids' weaning weight, type of sex within same breed was significantly $(\mathrm{p} \leq 0.05)$ affected weight in Desert kids only (Table 3$)$. Where male kids from Desert goats had larger body weight at weaning time $(11.88 \pm 0.45 \mathrm{~kg})$ compared with Taggar male kids $(8.70 \pm 0.20 \mathrm{~kg})$, where Desert female kids scored higher weight at weaning $(10.07 \pm 0.20 \mathrm{~kg})$ compared with Taggar female kids $(8.12 \pm 0.28 \mathrm{~kg})$. However, male kids in both breed scored higher body weight at weaning compared with female kids. The weaning weight difference between Desert and Taggar males was about $3.18 \mathrm{~kg}$, and between Desert and Taggar female about $1.95 \mathrm{~kg}$, the weaning weight difference between males and female in each breed was about $58 \mathrm{~g}$ and $1810 \mathrm{~g}$ for Taggar and Desert kids respectively.

Table3. Effect of sex on waning weight of Sudanese goats (means $\pm S E$ )

\begin{tabular}{|c|c|c|c|c|}
\hline & \multicolumn{4}{|c|}{ Weaning Weight (kg) } \\
\hline Variable & No & Male & No & Female \\
\hline Taggar goats & 8 & $8.70 \pm 0.20^{\mathrm{b}}$ & 8 & $8.12 \pm 0.28^{\mathrm{b}}$ \\
\hline Desert goats & 7 & $11.88 \pm 0.45^{\mathrm{a}}$ & 8 & $10.07 \pm 0.20^{\mathrm{a}}$ \\
\hline
\end{tabular}

${ }^{a b}$ Values in the same columns followed with different letters are significant at $P<0.001$

\section{DisCuSSION}

Birth weight is an economically important trait in livestock production. It is measure of prenatal growth and whish affect partially in post natal development. Bailgy and Mears (1990) reported that birth weight determine the future performance of individual engaged in prevailing environment. Thiruvenkadan et al., (2009) reported that sex, the period of birth and type of birth of kids were the major factors affecting birth weight in Tellichery goats. In This study showed that Desert males and female kids were heavier than Taggar male and female kids, This results were higher than that reported by Bushara et al., (2013) for Taggar kids, Abu Nikhaila and EL Hag (2003) for Nubian kids and lower than what reported by Tucho et al., (2000) for Boran Somali, Ugur et al., (2004) and ELAbid et al., (2008) for Nubian kids, Zeryhun (2006) for Abergelle kids, Zeleke (2007) for Somali goats in Eastern Ethiopia and Belay and Mengistie (2013) Abergelle kids. Generally the male's kids were heavier than their female contemporaries in both breed and this agree with Baiden (2007) and 
Gbangboche et al., (2006) who stated that the birth weight varied significantly from the different birth type and sex. Similar results were found by Liu et al., (2005), Ahuya et al., (2009); Jimenez-Badillo et al., (2009) and Bushara et al., (2013). The heaviest of male kids to female attributed to the anabolic effect of male sex hormones during pre-natal growth and to uterine environmental (Faiz et al, 1994), or may be due to the genotype of both the mother and the foetus play a vital role in determining the birth weight, while the consequent litter weights basically depend, beside the foetuses genotype, on the suckled milk from the dam (Abdel- Azeem, 2006). also may be due to what reported by Ugur et al., (2004) who observed that the difference in weight between both sexes may be due to the fact that the pregnancy period of does carrying male kids is usually longer (1-2 days) than those carrying female.

\subsection{Effect of Sex on Growth Rate}

The growth rate of the ruminant grazing tropical pastures or consuming crop residues alone are generally low and represent only about $10 \%$ of the animals genetic potential (Tedonkeng Pamo et al., 2002). Male kids were heavier at birth than female kids and tended to have a higher average daily gain, in this study the results showed that male gained more than female, and were heavier than female in subsequent growth rate and grew faster than female kids. In this study sex of kid significantly affected three months weight and daily body gain and this agree with Gbangboche et al., (2006) who indicated that sex, age of dam and kidding year are the important sources of variation for growth traits from birth till 3 months of age. Both kid sex from Taggar does were lighter at three months of age and daily body gain than kids from Desert does. Higher growth rate were obtained by Khadiga et al., (2008) and El-Abid (2008) for Nubian goats, Sundaram et al., (2012). The growth rate in pre weaning period was slightly higher in males than females. This is a natural phenomenon that male kids grow faster than females, as their mature weight is also heavier. Similar result was reported by Htoo et al., (2015), Dereje et al., (2015) for indigenous goats in Ethiopia and Assan (2013) who stated that body weight and growth rate of tropical goats are described to be low when compared with other temperate breeds.

Generally the differences in the pre-weaning weight gains are closely associated with the differences in level of milk intake during milk feeding period and the nutritional status of the doe (Debele et al., 2015). Or may also be due to the size and weight of dam and buck used at the time of mating, or possible due to higher nutrition might ensure subsequent better embryonic development during the pregnancy period. This agree with ELimam et al., (2007), Madibela et al., (2002), Abu Nikhaila and EL Hag (2003) and Sundaram et al., (2012) who suggested that the variation in body weight can be attributed to adaptations of kids to the region with time and environmental conditions with changes in weather parameters with interactions amongst different animals within the same breed.

\subsection{Effect of Type of Sex on Weaning Weight}

Weaning weight would reflect mothering ability of dam as well as the inherent growth potential. In this study it was found that the mean weaning weight of male Desert goat was higher than male Taggar goat. The reverse results were observed for female kids in both breed, this results online with Islam et al., (2009) who stated that the sex type has significant effect on weaning weight and male kids were slightly heavier than females at weaning. However, the mean weaning weight of male and female Desert kids were higher than male and female Taggar kids. In the current study the weaning weight of Desert goat similar to Ali (2010) for same breed, and was higher than what reported by Chowdhury et al., (2002), Kosum et al., (2004), Khadiga et al., (2008) for Nubian goats, and higher than what reported by Bushara et al., (2017) for Desert goat.

The weaning of Taggar kids male and female reported here was satisfy this results was similar to Acero-Camelo et al., (2008), Elabid (2002) reported weaning weight of Nubian kids were $8.641 \mathrm{Kg}$ and $8.150 \mathrm{Kg}$ for male and female respectively, and lower than what reported by Dereje et al., (2015) for Abergelle and Begait indigenous goats in Ethiopia and higher than what reported by Bushara et al., (2013) for Taggar goat. In weaning period the male exhibited higher weight than female kids, similar observations were claimed by Sexana et al., (1990), Gubartalla et al., (2002), Alexandre et al., (1999) and Abu Nikhaila and EL Hag (2003).The high weight gain for the male kids may be due to effect of male sex hormones and the aggressive nature of male during suckling and feeding.

The high weaning weight obtained in this study may be due to due to availability on feed from pasture quantity and quality during the rainy season which had direct influence on the dam's nutrition and 
hence amount of milk available to the unweaned kids. The discrepancies and difference in weaning weight of kids in this study and literature cited here may be due to breed variation and differences in management particularly the age of weaning. Males are in the majority of cases born heavier than females, this also translates in heavier weaning weights and growth rates for the male. The steroid hormone levels could have a role in this aspect, whereby, testosterone has a higher anabolic effect than estrogen. On the other hand, females face greater physiological stress in the form of pregnancy, kidding and nursing the kid, which drains the female's body reserves, thus lowering their body weights.

\section{CONCLUSION}

The result obtained in the current study, in general, showed that the growth performance of Desert and Taggar goats is medium as compared to Nubian goat breeds. The environmental factors like sex of kid affected weight at different ages and growth rates. The lower performance of female kids from both breed does need special attention as they delayed pubertal time and thus affect productivity of animal.

\section{ACKNOWLEDGEMENTS}

This study was supported by financial grants from Dalanj University. The authors wish to thank Abd Elaziz Omar for their assistance with livestock handling and management, the Nutrition Laboratory staff of ELObeid Agriculture Station, Abd alla Fdol.

\section{REFERENCES}

[1] Acero-Camelo, A., Valencia, E., Rodríguez, A., \& Randel, P. F. (2008). Effects of flushing with two energy levels on goat reproductive performance. Livestock Research for Rural Development ; 20 (9).

[2] Abu Nikhaila, Abdel Moneim, M. A., \& EL Hag, Khalid, O. (2003). Evaluation of growth rate of Sudan Nubian and crossbred kids. University of Khartoum. Journal of Agriculture Science, 11(1):134-143.

[3] Ahuya, C.O., Ojango, J.M.K., Mosi, R.O., Peacock, C.P., \& Okeyo, A.M. (2009). Performance of Toggenburg dairy goats in smallholder production systems of the Eastern highliands of Kenya. Small Rumin. Res., 83: 7-13.

[4] Ali, Bushara Hassan El.Tahir.(2010). Assessment of Some Productive and Reproductive Traits of Sudan Desert Goats under Conventional and Supplemented Feeding Systems. PhD. Thesis university of Khartoum, Sudan.

[5] Abdel-Azeem, A.S. (2006). A study of physiological and performance aspects in four pure breeds of rabbits and their crosses. MSc thesis, Faculty of agriculture, Fayoum University, Egypt.

[6] Assan, N. (2013). Various factors influencing birth weight in animal production. Scientific Journal of Review, 2(7): 156-175.

[7] Alexandre, G., Aumont, G., Maingud, G. C., Fleury, J., \& Naves. (1999). Productive performance of Guadeloupean Creole goats during the suckling period: Small Ruminant Research, 34(2): 157-162.

[8] Baiden, R.Y. (2007). Birth weight, birth type and pre-weaning survivability of West African Dwarf goats raised in the Dangme West District of the Greater Accra Region of Ghana. Tropical Animal Health and Production, 39 (2): 141-147

[9] Bailgy .C. B., \& Mears, G.J. (1990). Birth weight in calves and its relation to growth rates from birth to weaning and weaning to slaughter. Animal Breed Abstract, 58(10): 906.

[10] Belay, D., \& Mengistie, T. (2013). Evaluation of Growth Performance of Abergele Goats under Traditional Management Systems in Sekota District, Ethiopia. Pakistan Journal of Biological Sciences, 16: 692-696.

[11] Bembridge, T.J., \& Tapson, D.R. (1993) Communal livestock systems. In:Maree and Casey (Ed). Livestock Production Systems. Pretoria: Agriculture Development Foundation, pp 361373.

[12] Bushara, I., Abdelhadi, O. M. A., Elemam, M. B., Idris, A. O., Mekki, D. M., Muna, M. M. Ahmed., Abu Nikhiala, A. M., \& Ibrahim, E.(2013). Effect of sex of kids and Litter size on Taggar goat Kids performance. Archiva Zootechnica 16:2, 5-14. 
[13] Bushara, I., Hind, A. Salih., \& M. O. Mudalal. (2017). Birth and Weaning Weight of Sudanese Desert Goat as Affected by Management System. International Journal of Animal Husbandry and Veterinary Science, 2 (3): 10-11.

[14] Chowdhury S.A., Bhuiyan, M.S.A., \& Faruque, S. (2002). Rearing Black Bengal goat under semi-intensive management. 1. Physiological and reproductive performance. Asian-Australian Journal of Animal Science, 15:477- 484.

[15] Debele, S., Matiwos, H., Assmamaw, Y., \& Birhanu, A. (2015). Pre weaning growth performance of Bore cross with local goat in Gedio zone, Ethiopia. International Journal of Agriculture Science \& Veterinary Medicine, 3(3):14-20.

[16] Dereje,T., Mengistu, U., Getachew, A., \& Yoseph, M. (2015). A review of productive and reproductive characteristics of indigenous goats in Ethiopia. Livestock Research for Rural Development, 27 (2).

[17] Dossa, L. H., Wollny, C., \& Gauly, M. (2007). Smallholder's perceptions of goat farming in southern Benin and opportunities for improvement. Tropical Animal Production 39, 49-57.

[18] Dubeuf, J. P., \& Boyazoglu, J. (2009). An international panorama of goat selection and breeds. Livestock Science. 120:225-231.

[19] El-Abid, K. El-Hassan ., Babikerb, S.A., \& Abu Nikhaila, A.M.A.(2008). Growth Rates of Sudanese Nubian Kids under Smallholder System. International Journal of Dairy Science, 3: 170-178.

[20] El- Abid, K, H. (2008). Various factors affecting birth weight of Sudanese Nubian goat kids. Research Journal of Agricultural and Biology Science, 4(6): 700 - 703.

[21] El-Abid, K. E. (2002). Studies on some productive and reproductive traits of Sudan Nubian goats under village and small holder system. Ph. D. Thesis, University of Khartoum. Sudan.

[22] ELimam M.E., Tilal, M.A.M., \& Mohamed, K.A. (2007). Characterization of the Tagger goat in Eldelang area in the Nuba mountain in South Kordofan, Sudan. In: Conference on genetic resources of the Sudanese livestock wealth. Khartoum, 5-6 March.

[23] Elsharif, B.A. (2003). Effect of season on sexual behaviour, semen quality and fertility of Nubian, Saanen and crossbred bucks in Sudan. Thesis PhD, University of Khartoum, Sudan

[24] Faiz, M.A., Tufail, M.. Yaqoob, M., Younas, M., Ahmad, F., \& Nawaz, H. (1994). Production Traits of Beetal and Nachi Goats Associated with Birth Weight. Weaning Weight and Adult Weight. Pakistan Veterinary Journal, 3: 149-154.

[25] FAO. (2007). FAO production yearbook. Statistical Database, FAOSTAT WEB page. Food and Agricultural Organization of the United Nations. Rome, Italy, Vol. 51.

[26] Gbangboche A. B., Adamou-Ndiaye M., \& Youssao A. K. I. (2006). Non-genetic factors affecting the reproduction performancelamb growth and productivity indices of Djallonke sheep. Small Ruminant Research, 64: 133-142.

[27] Gubartalla K.E., Abu Nikhaila, A.M., \& EL Khidir, O.A. (2002). Some observations on performance of first kidding Sudanese Nubian goats. Sudan Journal of Animal Production, 15:43-54.

[28] Htoo Nay. Nang ., Khaing, Aung Tun., Abba, Yusuf., Htin, Nwe New., Faez, Jesse., Abdullah, Firdaus., Kyaw, Than., Khan, Mohd Azam Khan Goriman ., \& Lila, Mohd Azmi Mohd .(2015). Enhancement of growth performance in pre-weaning suckling Boer kids supplemented with creep feed containing alfalfa. Veterinary World; 8(6): 718-722.

[29] Islam, M. R., Amin, M. R., Kabir, A. K. M. A., \& Ahmed, M. U. (2009). Comparative study between semi-intensive and scavenging production system on the performances of Black Bengal goat. Journal Bangladesh Agriculture University 7(1): 79-86.

[30] Jimmy, S., David, M., Donald, K. R., \& Dennis, M. (2010). Smallholder Goat Breeding Systems in Humid, Sub-Humid and Semi Arid Agro-Ecological Zones of Uganda. Global Veterinaria 4: 283- 291.

[31] Jimenez-Badillo, M.R., Rodrigues, S., Sanudo. C., \& Teixeira, A. (2009). Non-genetic factors affecting live weight and daily gain weight in Serrana Transmontano kids. Small Ruminant. Research., 84: 125-128. 
[32] Khadiga M.E. Ballal., Mohamed-Khair A. Ahmed., \& Lutfi, M.A. Musa. (2008). Estimates of Phenotypic and Genetic Parameters of Growth Traits in the Sudanese Nubian Goat. Research Journal of Animal and Veterinary Sciences, 3: 9-14.

[33] Kosum, N., Taskin, T., Akbas, Y., \& Kaymakcia, M. (2004). Heritability estimation of birth and weaning weights in Saanen, Bornova and Saanen x Kilis goats. Pakistan Journal of Biology and Science; 7(1):1963-1966.

[34] Liu, W., Zhang, Y., \& Zhou, Z. (2005). Adjustment for non-genetic effects on body weight and size in Angora goats. Small Ruminant. Research., 59: 25-31.

[35] Madibela, O.R., Mosimanyana, B.M., Boitumelo, W.S., \& Pelaelo, T.D. (2002). Effect of supplementation on reproduction of wet season kidding Tswana goats. South African Journal of Animal Science 32:14-22.

[36] Saxena, V.K. K., Taneja, V.k., \& Bhat, P. N. (1990). Genetic and non genetic factors affecting pre-weaning growth in Jamunapari goats. Indian Journal of Animal Science, 60: 974-978.

[37] S.K.D.P. (2000). Southern Kordofan Development Program, Volume (1), Main Report. No. January 2000.Ibid p. xiii.

[38] SPSS. (1999). Statistical Package for Social Science version. Standard Version 10. SPSS Inc.

[39] Sundaram,Meenakshi, S., Muthuramalingam, T., Rajkumar, J.S.I., Nishanth, B., \& Sivakumar, T. (2012). Growth performance of Tellicherry goats in an organized farm. International Journal of Diary Science Research; 1(3): 9-11.

[40] Tabbaa, M. J., Alnimer, M. A., Amasheh, M. G., \& Barakeh, F.(2005). Age, Body Weight and Growth Rates to the Onset of Puberty of Mountain Black, Damascus Doe Kids and Crossbreds as Affected by Season of Birth and Birth Type. Dirasat, Agricultural Sciences, 32(3): 296-303.

[41] Tedonkeng-Pamo, E., Tendonkeng, F., Kadjio, J. T. T., Kwami, H. N., Taboum, R. K., Kana, J. R., \& Tegodjeu, A. (2002). Evaluation of the comparative growth and reproductive performance of West Africa Dwarf goats in the western highlands of Cameroon. In Development and field evaluation of animal feed supplementation packages, proceedings of the final review meeting of an IAEA, 25-29 Nov 2000, Cairo, Egypt, Vienna, P.87-96.

[42] Thiruvenkadan, A.K., Murugan, M., Karunanithi, K., Muralidharan, J., \& Chinnamani, K. (2009). Genetic and non-genetic factors affecting body weight in Tellicherry goats. 10th World Conference on Animal Production. South Africa Journal of Animal Science., 39 (Supplement 1)

[43] Tucho, T.A., Regassa, A., \& Fita, L. (2000). Preliminary Production and Reproduction Performance Evaluation of Mid Rift Valley and Borana Somali Goats. In: The Opportunities and Challenges of Enhancing Goat Production in East Africa, Merkel, R.C., G. Abebe \& A.L. Goetsch (Eds.). Debub University, Awassa, Ethiopia.

[44] Ugur F., Savas, T., \& Dosay, M. (2004). Growth and behavioural traits of Turkish Saanen kids weaned at 45 and 60 days. Small Ruminant Research, 52: 179-184.

[45] Zeleke, Z.M. (2007). Environmental influences on pre-weaning growth performances and mortality rates of extensively managed Somali goats in Eastern Ethiopia. Livestock research for rural development, 19(12).

[46] Zeryhun, M. (2006). Goat husbandry practices and productive performances in Sekota district of Amhara Region. M.Sc. Thesis, Haramaya University, Haramaya. 